\title{
PERFORMANCE APPRAISAL AND ITS IMPACT ON INTRINSIC FACTORS THAT INFLUENCE FACULTY MEMBERS MOTIVATION: A STUDY ON HIGHER EDUCATIONAL INSTITUTES OF ISLAMABAD AND RAWALPINDI IN PAKISTAN
}

\author{
Usamah Shakeel \\ Research Scholar, \\ School of Management Science and Engineering, Tianjin University, \\ Tianjin, China \\ Email: usamah.shak331@yahoo.com
}

\begin{abstract}
Organizational goals are achieved via the use of performance appraisal (PA), which is designed to enhance workers' contributions to the attainment of those objectives. However, unless a performance assessment system is seen to be equal, appraisers and appraises are unlikely to react positively to it. A surprisingly small amount of empirical research has been done on the relationship between faculty members' motivation and performance appraisal in higher educational institutions, despite recent research efforts into the experiences of organizational commitment, particularly in developing economies. The study is a survey with objective to establish the relationship between performance appraisal and its effect on intrinsic factors of employee's motivation in Higher Educational Institutes of Pakistan. The study was conducted on higher educational institutes of Pakistan; however, sample will be collected from universities of twin cities. The study in hand is classified in to explanatory and quantitative. Primary source of data will be used to gather the data. A survey was conducted to distribute a questionnaire among all faculty members, collecting data from them and then data will be evaluated to find the results. To inspect the outcome of performance appraisal on employee's motivation, Frequency, Percentage and Correlation method was utilized with SPSS tool. Results show that performance appraisal system has impact on Employee Motivation in Higher Educational Institutes and Intrinsic factors also has impact on motivation. Conclusion and recommendations are also discussed.
\end{abstract}

\section{KEYWORDS}

Performance Appraisal, Employee Motivation, Intrinsic Factors, Pakistan

\section{INTRODUCTION}

Cardy (1994), describes how an organization can improve its human resource 
management. This can affect employees' attitudes towards companies and their motivations. This improves the workers' understanding of and approach to work responsibilities. Employees must be honest about their work performance. This will help managers make career decisions, as well as future promotions, and to adjust their pay. (Schuler 2002).

Employees will benefit from receiving feedback that provides information specific to their performance. Employees can learn from their feedback what works well and what doesn't. It is common to believe that first-line manager has difficulty being evaluated. Popoola (1990), researcher, stated that lower-level job descriptions are generally easier to evaluate. When analyzed closely, even the easiest jobs can present challenging evaluation challenges.

Performance evaluation is a useful tool for motivating workers and leaders, encouraging lifetime learning, and encouraging individuals and teams to demonstrate complete performance. Performance evaluation does not evaluate individual production, but also the behavior of employees. To avoid conflict or keep its "face" intact, the business will not divulge to employee's performance evaluation results (Shen, 2004).

An example case study involving an equity bank in Kenya illustrates the impact of performance assessment on employee motivating. This study helps identify positive as well as negative variables that can affect turnover and absenteeism of employees at commercial banks. The research also examines what feedback and performance assessment have on employees' motivation. Some of the participants to the survey stated that they receive official staff evaluations twice a decade. Researchers used a questionnaire to collect data, which was then analyzed within the Statistical Package for the Social Sciences. Research was conducted using both descriptive statistics and thematic analyses. Data were presented in frequency charts, bar graphs, or table format. The PA of Bank was opaque and did not act in a fair manner. The bank did not make any mention of its performance criteria and goals. There was strong statistical significance to the finding of positive correlation between feedback results and employee motivation. (Kirai \& Kisang, 2016)

This research is designed to assess the impact of management trust on performance evaluations. These studies help to understand trust and the factors that contribute to it. A quasi experiment tests the impact of company performance assessment systems on top management trust. Next is route research, which studies trustworthiness' impact on trust system insights. Data could be obtained from three models: the global factor model (a null model), and a regression. It is possible to draw the conclusion that trust among senior executives varies according to their level and experience. There was no 
difference in trustworthiness between the old PA system's counterparts (ability to benevolence/honesty). The new evaluation technique did not affect the value of any factor. (Davis and Mayer, 1999).

Employee motivation can be affected based on how they view their performance rewards. This study was designed to determine how different human resources systems impact motivation and retention in non-teaching personnel in public secondary schools. We used both a simple random sampling approach and a deliberate selection method to select our respondents. Data collection methods included questions and interviews. To analyze data, descriptive statistics was used. They covered frequency, percentages as well as means and other statistics. Interview data was subject to thematic analysis. The findings were succinctly summarized using frequency tables and bar graphs. This study concluded that secondary school staff in Eldoret West District used public address systems to boost employee enthusiasm, and decrease withholding. Public secondary school employees performed better and were more involved as a consequence. They also stayed on their posts more often, which was due merit pay. Prisca oluoch (2006),

Studies show that HR practices may influence employee motivation. Further research is needed in order to understand how this effect affects academics at Nigerian Universities. This study looked at how performance appraisal (PA), a crucial human resource tool, affected academic motivation in Nigerian university. It used four public institutions located in southern Nigeria as its study sample. The questionnaire collected the data. The results of the survey were analyzed using percentages, multiple analysis, and other methods. The purpose of the study was to assess whether academics were aware about the fairness and accuracy in their university's performance-assessment system. Academics are all aware of the flaws in their university's appraisal system. It doesn't stop all the work activities related to their performance over time. The performance appraisal system had a major impact on academic motivation, and general performance. University management must reform the PA system so that all academic components are accurately documented and assessed. (OJOKUKU, 2013).

This study was undertaken to understand how PA impacts the motivation of Islamic Banking employees. Shariah compatible human resources methods have been used in Asian countries, like Pakistan, that recently launched Islamic banking. SPSS programming linked linear regression and spearman's correlation techniques to permit analysis. The researchers used a quantitative technique to analyze the relationship between PAs. This method is also known as the deductive. 100 people took part in the study. Surveys are the best method to collect primary information. The positive relationship between PA, employee satisfaction, and Islamic banking has been shown by regression and correlation. Research has shown that PA has a significant influence 
on the motivation of Islamic banks workers. (Saeed S and Shah, 2016).

\section{LITERATURE REVIEW Performance appraisal}

Employee evaluation can also be described as the assessment and discussion of employee performance in the workplace with the goal to improve (Koretz et al. 1996) Performance evaluation is the measurement of employee performance in order to set goals and/or predict future output. Both practitioners and academics debate the importance evaluation in human resources management. Performance management covers both past performance evaluations (and future goals. (McKenna et al. 2002). Managers view employee contributions to an organization as the highest value personnel/human resources result (Heneman 1986).

Job descriptions are a guideline for what employees should do when they work. Evaluations are done by comparing employee performance to establish goals. (Westover and L.A., 2010) state that employees should have their performance evaluated on a consistent basis throughout their career. It is the most difficult job of a manager to conduct an annual staff appraisal. Many methods can be used to appraise staff. However, the system that is chosen should reflect the organization's culture. Many performance assessment authors understand that it is hard to strike the right balance among compliance concerns, employee expectations, and corporate controls. Each year, an appraisal is conducted by financial institutions at the close of every fiscal year. It is typically performed by the immediate supervisor. On the opposite side, the immediate supervisor conducts monthly evaluations of the bank's selling team. Interviews can provide useful information, both from the employee as well as internal records.

\section{Intrinsic Factors that Influence Employee Motivation}

Intuitively motivating yourself means being able to do well at work and achieving your personal goals. People can feel intrinsically driven if they take action that results in a certain state of mind (such as pride over a job completed). Many people don't find themselves motivated by external factors like money, fame, hunger, or wealth. However, intrinsic motivations can be satisfied by work. This is due to the fact that duty offers opportunities for growth as well achievement and new challenges. A person's ability to feel, have capacity, and make choices about their behavior is a key indicator of how motivated they are. One, a person can seek out challenges to help discover more about him or herself and assert his/her personal power (Matthew et al. 2009).

\section{Recognition and Employee Motivation}

According to Maurer's (Kamalian.et.al. 2010), recognition and incentives are key 
components for employee happiness and motivation. These two elements have a direct influence on an organization's ability to perform (Jun, et.al. 2006). Author observed a link between Pakistani bank employees' motivations and Pakistani incentive programs. The motivation he looked into was credit. He measured it with Pearson. According to the study's results, recognition was strongly correlated in employee motivation (Kamalian.et.al. 2010).

\section{Skill Variety}

This indicates that a broad range of skills is required to perform a particular task (Dr. Peter R et al., 2011). Because an assembly-line worker performs the same tasks repeatedly, there is less chance that he will choose a job. As job importance grows, skill levels also increase. Dockel et.al. (2006) stated that employees can feel more competent if they are given work that requires them to use a variety different ability. A diversity of talents fosters loyalty and belonging in the company. (Dr. Peter R et al., 2011) cautioned not to confuse skill variety with multitasking. This allows you to perform multiple tasks simultaneously using a smartphone or laptop.

\section{Trust}

Trust is key to a business's longevity, success, and sustainability. It is possible to have both external and internal relationships affected. However, it is also possible for interpersonal and personal interactions and the business to have an effect on them (Annamalai et al.2010).

\section{Total Life Space}

Total Number of years in Universe. Human Resource professionals are still relatively new to the idea of "whole life spaces". But this concept is gaining popularity as more employees are involved. Employees should be capable of finding the right balance between work obligations and personal ones. Therefore, people expect supervisors and managers (Kamalian.et.al. 2010)

\section{Meaningful Work}

Related to the desire for meaningful work. Managers must make their work meaningful to employees to encourage them to be motivated and to positively impact their business. Relevant work experiences are those that have been recognized, achieved, and held positions (Yaseen, 2013).

\section{Training and Development}

It is the best way for employees to develop their skills. Individuals who have had training tend to be more dedicated than those without experience (Abdullah and $\mathrm{R}$ Djebavni , 2011). These sessions provide employees with the opportunity to develop and grow their skills (Hunjra et al. 2010). Many programs for coaching, management, 
training and coaching were created to match the capabilities of employees with the organizational potential (Hunjra et al., 2010).

\section{Task Significance}

Task significance is the measure of how much someone feels that their work has an influence on others' lives (Chiang et al., 2008). Many people choose to work to make a living. There are many rewards to being creative.

\section{Impact of Performance Appraisal Process on Employee Motivation}

Lewis et al., (2003) state that performance appraisal is a method to influence and communicate the job executions of employees and create strategies to improve delegating of work tasks. Herbert, (2009) describe the role of performance evaluation in shaping employee performance. The value of performance evaluation lies in the data it provides regarding employee performance, the identification or training needs, and the creation/implementation of staff development plans. Performance assessment systems are generally accepted as a way to increase employee motivation (Collins, C.J., \&Clark, K.D., 2003).

Dockel et.al. (2006) breaks down performance evaluation techniques into four phases. Performance principles can also be used in individual performance evaluations. These are methods to shape the system and compare it with performance principles. They also provide a way for you to evaluate your performance. All this starts with creating a job profile. The job description and actual performance must be compared. The second step involves associating employee performances. In the last step, we will compare. The job's core principles serve as a basis for assessing individual effort. This comparison allows you to calculate your performance. This is also the last step. Cloninger and Selvarajan (2009) reported that many businesses don't like their performance evaluations. They also reported that this process made it difficult for employees to be motivated. Although performance assessment is not essential it is important to build a positive environment at work and improve service quality. (Selvarajan and Cloninger, 2012) points out that performance appraisal can lead to many problems. They include an inability, understanding, or willingness to confront poor performances. Next, we'll look at the motivational effects of various performance analyses. This will include both past experiences and the future. This section will cover methods that are built on the past.

\section{Past-Oriented Methods}

\section{Rating Scales}

The rating system allows for systematic evaluations. Every employee attribute has a value. They can range anywhere from poor presentation to excellent presentation. Important is the measurement unit size. This method allows employees and managers 
compare their performance to that of the entire workforce (Ali et al., 2012). These standards serve as the performance measurement standard for the entire company. These standards are also impartial for all employees. They are popular for their ease of use and acceptance (Barringer et al., 2005) this method may not be applicable to all types of jobs. It is also not a reliable way to determine if a worker has the right abilities (Ali et al., 2012).

\section{Checklist Procedure}

As part of this process, you'll need "Statements on Characteristics" created for each employee. These will be a series, YES/NO questions. The rater is responsible for ensuring that all information is accurate and complete. While the actual assessment is made by the human resources section (Okeyo, et al., 2010). All answers from the appraisers need to be verified. After the checklists have been completed, they are submitted for further actions to human resource. The checklist may not have all the questions equal weight. The most important may be given a greater weight. The whole score set, including employee assessment, is reviewed by the human resource department. This method can be implemented easily, is affordable, feasible to administer, comparable with training requirements, cost-effective, and practical. Raters cannot provide relative assessment due to biases or wrong weights (Caruth et al., 2008).

\section{Method of Forced Selection}

Announcements in the force selection procedure are presented and assessed to determine if they're true. Before proceeding, a rater has to first decide. The department that is responsible for human resources is responsible. While forced selection is a way to eliminate personal preferences (Denby and steve, 2010) the downside is poorlyconstructed sentences. Large corporations often have to deal with overoptimistic raters. They can either be too complicated, or they can be too basic. This strategy is meant to avoid the problem by requiring that all employees be evaluated on a range between good and bad. (Ichniowski,C. and Shaw, 2009).

\section{Methodologies Oriented Toward the Future MBO}

Peter Drucker, a well-known manager theorist, was born in 1886 . He promoted management objectives in large numbers starting in the 1950s. What drives them is the final result from performance appraisal MBO measures. This means that employees get evaluated on how well they have performed in relation to their job responsibilities. The boss and the employee need to be on the exact same page regarding the goals. Employees are required to do an audit of the goals they set in order to find the appropriate skills. They don't rely upon others to help understand and find their weaknesses and strengths. They need to practice self-control in order to manage their 
growth and development (Porter and M. E, 2008).

\section{Methods Used by Assessment Centers}

Employers can use the assessment centers for job estimation under the supervision and oversight of certified assessors. This involves more than just observing behavior through series, or working examples. Participant in roleplaying or computer simulations must ensure they are participating in in-basket activities, work group and those (Qureshi et al., 2007). More useful is the ability to accurately predict future performance, growth and with the aid of a well-established calculation system. Assessment centers are highly valued for being reliable, valid, and having analytical capabilities. It prevents hiring and endorsing incompetent candidates. It also includes information on how candidates get promoted and chosen. Because it relies on latent future performance, the other method doesn't take into account past performance. The cost of hiring psychologists is high as the employees have to travel and must stay at hotels. While assessment requires interpersonal skills such as empathy, some poor performers may be overwhelmed by virtual environments (Porter and M. E, 2008).

\section{0-degree Evaluation}

All groups of individuals with whom an employee interacts in the course of his work, including immediate supervisors, team members, customers, peers, subordinates, and himself get various weights for the practice of collecting performance data/feedback/ratings (Ohabunwa, 2009). This strategy's utility and effectiveness have been confirmed by numerous studies. This strategy is capable of assessing personal skills and client satisfaction as well team-building talents. This strategy offers the greatest advantage. Assessors must not overlook any constituency. This makes it more difficult, more expensive, and more time-consuming to gather information from multiple sources (Ichniowski,C. and Shaw, 2009).

\section{Psychological Evaluations}

These assessments emphasize the potential of future accomplishments and less on past performance. Final results will be determined by in-depth interviews. Psychological testing, supervisor talks, and reviewing previous evaluations. It focuses on the personal, emotional, and motivational aspects of an employee which may have an impact on his or her work (Ohabunwa, 2009) This is a great method for wealthy young people looking to uncover their true fortune. These assessments can be very successful, but they will not always be accurate or precise (Ichniowski,C. and Shaw, 2009)

\section{RESEARCH OBJECTIVES}

1. To analyse the effect of performance appraisal on employee's motivation in Rawalpindi and Islamabad HEI of Pakistan.

2. To assess the effect of intrinsic factors of trust, Recognition of work and training 
and development on Motivation.

\section{RESEARCH QUESTIONS}

1. What is the effect of performance appraisal on employee's motivation in Rawalpindi and Islamabad HEI of Pakistan?

2. What is the effect of intrinsic factors of trust, Recognition of work and training and development on Motivation?

\section{RESEARCH HYPOTHESIS}

1. Performance appraisal system has impact on Employee Motivation in Higher Educational Institutes.

2. Intrinsic factors has impact on motivation.

\section{RESEARCH METHODOLOGY}

Study objectives or hypotheses can only be known if the research strategy is followed. It's a comprehensive strategy outlining how data will be gathered and analyzed. Research challenges or opportunities are addressed by creating a framework. In order to get responses from a large number of people, this research used a quantitative approach. The research used a quantitative approach to get responses from a sample. This study used a descriptive research strategy. As a result, the researcher is looking for a correlation between the different factors in the study.

\section{Population}

All faculty members at Pakistan's universities in Rawalpindi and Islamabad are included in this study's demography.

\section{Data gathering}

A standardized questionnaire was used to collect information. Questionnaire was distributed to all faculty members of HEI in Islamabad and Rawalpindi.

\section{Analysis of data}

Completed surveys were checked for accuracy and completeness before being processed. Data were coded to make statistical analysis easier using the SPSS software. Frequencies and percentages are descriptive statistics used in data analysis. The significance of the connection between PA and intrinsic motivational factors in Rawalpindi and Islamabad HEI were determined using Pearson's correlation coefficient.

Three intrinsic factors of employee motivation are shown below in Figure 1:

\section{Trust}

Motivation Training \& Development 
Recognition of Employee Work

Figure 1 Factors of motivation

\section{FINDINGS AND RESULTS}

To provide the foundation for the study, the researcher asked respondents in Section I of the questionnaire for some fundamental information. These are some of the general information findings:

Table 1: Gender of Respondent

\begin{tabular}{llcccc}
\hline & & Frequency & Percent & $\begin{array}{c}\text { Valid } \\
\text { Percent }\end{array}$ & $\begin{array}{c}\text { Cumulative } \\
\text { Percent }\end{array}$ \\
\hline Valid & Male & 167 & 67.6 & 67.6 & 67.6 \\
& Female & 80 & 32.4 & 32.4 & 100.0 \\
& Total & 247 & 100.0 & 100.0 & \\
\hline
\end{tabular}

According to the results, $32.4 \%$ of the respondents were females and $67.6 \%$ men.

Table 2: Respondents' Education Level

\begin{tabular}{lccccc}
\hline & & & Valid & Cumulative \\
Valid & Frequency & Percent & Percent & Percent \\
\hline & Machelor & 49 & 19.8 & 19.8 & 19.8 \\
& PhD & 122 & 49.4 & 49.4 & 69.2 \\
& 61 & 24.7 & 24.7 & 93.9 \\
& Diploma & 9 & 3.6 & 3.6 & 97.6 \\
M.Phil. & 4 & 1.6 & 1.6 & 99.2 \\
& Ms. Business & 2 & .8 & .8 & 100.0 \\
& Administration & & & & \\
Total & 247 & 100.0 & 100.0 & \\
\hline
\end{tabular}

The results of this study indicate how educated participants were. $19.8 \%$ of the respondents have a bachelor. $49.4 \%$ possess a masters. $24.7 \%$ of respondents possess a $\mathrm{PhD}$. $3.6 \%$ hold diploma degree. $1.6 \%$ and $0.8 \%$ of respondents hold a master's degree respectively. Table 2 shows that most respondents have a masters.

Table 3: Respondents' Work Experience

\begin{tabular}{llcccc}
\hline & & Frequency & Percent & $\begin{array}{c}\text { Valid } \\
\text { Percent }\end{array}$ & $\begin{array}{c}\text { Cumulative } \\
\text { Percent }\end{array}$ \\
\hline Valid & 0-4 years & 85 & 34.4 & 34.4 & 34.4 \\
& 5-9 years & 85 & 34.4 & 34.4 & 68.8 \\
& 10-14 years & 65 & 26.3 & 26.3 & 95.1 \\
& 15-19 years & 2 & .8 & .8 & 96.0 \\
\hline
\end{tabular}




\begin{tabular}{ccccc}
\hline over 20 years & 10 & 4.0 & 4.0 & 100.0 \\
Total & 247 & 100.0 & 100.0 & \\
\hline
\end{tabular}

Table 3 shows $34.4 \%$ respondents have at minimum 0-4 years' experience in HEI. $34.4 \%$ have 5-9 years' experience, $26.3 \%$ have $10-14$ year, $0.8 \%$ have $15-19,4 \%$ has over 20 years' experience. These results show the majority of respondents have 5-9 years' experience.

Table 4: Respondents' Position

\begin{tabular}{cccccc}
\hline & & & Valid & Cumulative \\
& & Frequency & Percent & Percent & Percent \\
\hline Valid & Junior Lecturer & 53 & 21.5 & 21.5 & 21.5 \\
& Lecturer & 98 & 39.7 & 39.7 & 61.1 \\
& Assistant Professor & 56 & 22.7 & 22.7 & 83.8 \\
Associate Professor & 21 & 8.5 & 8.5 & 92.3 \\
Professor & 9 & 3.6 & 3.6 & 96.0 \\
HOD & 2 & .8 & .8 & 96.8 \\
& 2 & .8 & .8 & 97.6 \\
Project Manager & 2 & 1.6 & 1.6 & 99.2 \\
Coordinator & 4 & .8 & .8 & 100.0 \\
Lab Engineer & 2 & 100.0 & 100.0 & \\
Total & 247 & & &
\end{tabular}

Table 4 shows that $21.5 \%$ of respondents are Junior Lecturer, $39.7 \%$ are Lecturer, $22.7 \%$ are Assistant Professor, $8.5 \%$ are Associate Professor, 3.6\% are Professor, $0.8 \%$ are HOD, $0.8 \%$ are Project Manager, $1.6 \%$ are Coordinator and $0.8 \%$ are Lab Engineer. Thus, the findings indicate that majority of the respondents are Lecturers.

Table 5: Respondents' organizations

\begin{tabular}{llrrrr}
\hline & & & Valid & Cumulative \\
& & Frequency & Percent & Percent & \multicolumn{1}{c}{ Percent } \\
\hline Valid & CASE & $\mathbf{2 0}$ & $\mathbf{8 . 1}$ & $\mathbf{8 . 1}$ & $\mathbf{8 . 1}$ \\
& FAST & 31 & 12.6 & 12.6 & $\mathbf{2 0 . 6}$ \\
& Iqra University & 40 & 16.2 & 16.2 & 36.8 \\
ARID & 32 & 13.0 & 13.0 & 49.8 \\
CUST & 30 & 12.1 & 12.1 & 61.9 \\
Preston & 20 & 8.1 & 8.1 & 70.0 \\
Comsats & 30 & 12.1 & 12.1 & 82.2 \\
BIMS & 16 & 6.5 & 6.5 & $\mathbf{8 8 . 7}$ \\
Garrison Degree & 14 & 5.7 & 5.7 & 94.3 \\
College & & & & \\
\hline
\end{tabular}




\begin{tabular}{lrrrr}
\hline $\begin{array}{l}\text { Foundation } \\
\begin{array}{l}\text { University } \\
\text { Total }\end{array}\end{array}$ & 14 & 5.7 & 5.7 & 100.0 \\
\hline
\end{tabular}

Table 5 shows that $8.1 \%$ of respondents are from CASE University, $12.6 \%$ are from FAST, $16.2 \%$ are from IQRA UNIVERSITY, 13\% from ARID, 12.1\% from CUST, 8.1\% from Preston, $12.1 \%$ from COMSATS, 6.5\% from BIMS, 5.7\% from Garrison Degree College and $5.7 \%$ from Foundation University. Thus, the findings indicate that majority of the respondents are from IQRA UNIVERSITY.

Table 6: Appraisal system followed in organization is

\begin{tabular}{cccccc}
\hline & & & $\begin{array}{c}\text { Valid } \\
\text { Prequency }\end{array}$ & $\begin{array}{c}\text { Cumulative } \\
\text { Percent }\end{array}$ \\
\hline Valid & 169 & 68.4 & 68.4 & 68.4 \\
& Self- & & & & \\
& Assessment/General & & & & \\
Appraisal & & 14.2 & 14.2 & 82.6 \\
& 360-Feedback & 35 & 12.1 & 12.1 & 94.7 \\
& Essay Evaluation & 30 & 5.3 & 5.3 & 100.0 \\
& Paired Comparison & 13 & 100.0 & 100.0 & \\
Total & 247 & & & \\
& & & &
\end{tabular}

Table 6 shows that Self-Assessment Appraisal System being followed by $68.4 \%$. $14.2 \%$ had been following 360-Feedback. $12.1 \%$ had been following Essay Evaluation. 5.3\% had been following Paired Comparison. These results demonstrate that Self-Assessment appraisal System represents the best method of evaluation for most organizations.

Table 7: Current appraisal system in your organization based upon

\begin{tabular}{cccccc}
\hline & & Frequency & Percent & $\begin{array}{c}\text { Valid } \\
\text { Percent }\end{array}$ & $\begin{array}{c}\text { Cumulative } \\
\text { Percent }\end{array}$ \\
\hline Valid & Quality Of Work & 95 & 38.5 & 38.5 & 38.5 \\
& Quantity Of Work & 22 & 8.9 & 8.9 & 47.4 \\
Goals Achieved & 96 & 38.9 & 38.9 & 86.2 \\
Last Year & & & & \\
All & 25 & 10.1 & 10.1 & 96.4 \\
$\quad$ None & 2 & .8 & .8 & 97.2 \\
& $\begin{array}{c}\text { Quality and } \\
\text { Quantity of Work }\end{array}$ & 6 & 2.4 & 2.4 & 99.6 \\
all and admin & 1 & .4 & .4 & 100.0 \\
responsibilities & & & & \\
Total & 247 & 100.0 & 100.0 & \\
\hline \hline
\end{tabular}


Table 7 shows that $38.5 \%$ rely on quality of work for their current appraisal system. $8.9 \%$ are based entirely on the work done. $38.9 \%$ of them depend entirely on the goals achieved in the past year. $10.1 \%$ is based entirely upon all, $0.8 \%, 2.4 \%$, quality and quantity and $0.4 \%$, all and administrative responsibilities. The results indicate that the vast majority of Organizations Current Appraisal Systems are based upon the goals achieved last year.

Table 8: I would like performance appraisal further to be based upon

\begin{tabular}{cccccc}
\hline & & & Valid & Cumulative \\
Valid & Frequency & Percent & Percent & Percent \\
\hline & Quality Of Work & 103 & 41.7 & 41.7 & 41.7 \\
Quantity Of Work & 22 & 8.9 & 8.9 & 50.6 \\
Goals Achieved & 101 & 40.9 & 40.9 & 91.5 \\
Last Year & & & & \\
All & 10 & 4.0 & 4.0 & 95.5 \\
$\quad$ None & 6 & 2.4 & 2.4 & 98.0 \\
Quality and & 4 & 1.6 & 1.6 & 99.6 \\
Quantity of Work & & & & \\
all and admin & 1 & .4 & .4 & 100.0 \\
responsibilities & & & & \\
Total & 247 & 100.0 & 100.0 & \\
\hline
\end{tabular}

Table 8 shows that $41.7 \%$ prefer Performance Appraisal to be based on the quality of work. 8.9\% of respondents prefer it to base on Quantity and $40.9 \%$ prefer to it to base upon Achievements in the Last Year. $4 \%$ on All, $2.4 \%$ on None, $1.6 \%$ based On Quality and Quantity work, and.4\% based on all administrative responsibilities. According to these results, the majority of respondents wish that Performance Appraisal should also be based upon quality of work.

Table 9: The frequency of appraisal in organization is

\begin{tabular}{cccccc}
\hline & & Frequency & Percent & $\begin{array}{c}\text { Valid } \\
\text { Percent }\end{array}$ & $\begin{array}{c}\text { Cumulative } \\
\text { Percent }\end{array}$ \\
\hline Valid & Monthly & 2 & .8 & .8 & .8 \\
& Quarterly & 11 & 4.5 & 4.5 & 5.3 \\
& Bi-Annually & 77 & 31.2 & 31.2 & 36.4 \\
& Annually & 157 & 63.6 & 63.6 & 100.0 \\
& Total & 247 & 100.0 & 100.0 & \\
\hline
\end{tabular}

Table 9 displays the frequency with which organizations use appraisals: $0.8 \%$ monthly, 
$4.5 \%$ quarterly, $31.2 \%$ twice-yearly and $63.6 \%$ annually. The results showed that organizations use appraisals more often every year.

Table 10: Does performance appraisal address personality traits

\begin{tabular}{cccccc}
\hline & & Frequency & Percent & $\begin{array}{c}\text { Valid } \\
\text { Percent }\end{array}$ & $\begin{array}{c}\text { Cumulative } \\
\text { Percent }\end{array}$ \\
\hline \multirow{7}{*}{ Valid } & Yes & 160 & 64.8 & 64.8 & 64.8 \\
& No & 87 & 35.2 & 35.2 & 100.0 \\
& Total & 247 & 100.0 & 100.0 & \\
\hline
\end{tabular}

Table 10 shows the results. Respondents chose Yes $64.8 \%$ and respondents chose No $35.2 \%$. Performance Appraisal addresses personality attributes, according the results.

Table 11: Does appraisal form contain the feedback column

\begin{tabular}{lccccc}
\hline \multicolumn{1}{|c}{ Valid } & & Frequency & Percent & $\begin{array}{c}\text { Valid } \\
\text { Percent }\end{array}$ & $\begin{array}{c}\text { Cumulative } \\
\text { Percent }\end{array}$ \\
& Yes & 181 & 73.3 & 73.3 & 73.3 \\
& No & 66 & 26.7 & 26.7 & 100.0 \\
& Total & 247 & 100.0 & 100.0 & \\
\hline
\end{tabular}

Table 11 shows that respondents selected Yes $73.3 \%$ for the survey, and No $26.7 \%$ for the questionnaire. These results indicate the inclusion of the Feedback Column in appraisal forms.

Table 12: Which factor is most important for you

\begin{tabular}{cccccc}
\hline & & & Valid & Cumulative \\
& & Frequency & Percent & Percent & Percent \\
\hline Valid & Trust & 62 & 25.1 & 25.1 & 25.1 \\
& Recognition of Work & 123 & 49.8 & 49.8 & 74.9 \\
& Training and & 62 & 25.1 & 25.1 & 100.0 \\
& $\begin{array}{c}\text { Development } \\
\text { Total }\end{array}$ & 247 & 100.0 & 100.0 & \\
\hline
\end{tabular}

Table 12 shows how respondents chose Trust to choose from, while $49.8 \%$ selected Recognition of Work and 25,1\% chose Training and Development. These results reveal that Recognition of Work is the most important element for respondents.

\section{Hypothesis Results}

\section{Performance with motivation}

In Table 13 the results of a test to determine whether the motivation and the performance evaluation system are linked are shown $\left(\mathrm{r}=.629^{* *}, \mathrm{p}=, 000\right)$. You can see by looking at the table above that motivation has a strong and statistically significant 
connection to the overall performance evaluation system. This demonstrates that motivating employees has a beneficial effect on performance evaluation. Alternatively, it may mean that appraisers have a positive view of the evaluation system as a whole due to the nature of assessment procedures like the appraisal process.

Table 13: Performance with motivation correlation

\begin{tabular}{cccc}
\hline & & Performance & Motivation \\
\hline Performance & Pearson Correlation & 1 & $.629^{* *}$ \\
& Sig. (2-tailed) & & .000 \\
$\mathrm{~N}$ & 247 & 247 \\
\cline { 1 - 3 } Motivation & Pearson Correlation & $.629^{* *}$ & 1 \\
& Sig. (2-tailed) & .000 & \\
$\mathrm{~N}$ & 247 & 247 \\
\hline **. Correlation is significant at the 0.01 level (2-tailed).
\end{tabular}

\section{Motivation with training}

Table 14 shows the results of a study to see whether motivation and training are correlated. the Table shows a high positive connection between overall motivation and training $\left(\mathrm{r}=.724^{* *}, \mathrm{p}=, 000\right)$ because of HEI's provision of sufficient education in evaluation form, organizations encourage the efforts of workers to acquire training on new abilities, increasing the motivation of faculty.

Table 14: Motivation with training correlation

\begin{tabular}{cccc}
\hline & & Motivation & Training \\
\hline Motivation & Pearson Correlation & 1 & $.724^{* * *}$ \\
& Sig. (2-tailed) & & .000 \\
Training & $\mathrm{N}$ & 247 & 247 \\
& Pearson Correlation & $.724^{* *}$ & 1 \\
& Sig. (2-tailed) & .000 & \\
$\mathrm{~N}$ & 247 & 247 \\
\hline & $* *$ Correlation is significant at the 0.01 level (2-tailed).
\end{tabular}

\section{Motivation with recognition}

Table 15 shows the results of a test to determine the relationship between motivation and the acknowledgment of one's efforts. Because HEIs acknowledge good work done during the evaluating period, organizations provide reward programs for faculty members and organizations provide constructive criticism about faculty members' work, as shown in the Table $\left(\mathrm{r}=.569^{* *} . \mathrm{p}=.000\right)$, there is a strong positive correlation between overall motivation and work recognition. 


\begin{tabular}{|c|c|c|c|}
\hline & & Motivation & Recognition \\
\hline \multirow[t]{3}{*}{ Motivation } & $\begin{array}{c}\text { Pearson } \\
\text { Correlation }\end{array}$ & 1 & $.569^{* *}$ \\
\hline & Sig. (2-tailed) & & .000 \\
\hline & $\mathrm{N}$ & 247 & 247 \\
\hline \multirow[t]{3}{*}{ Recognition } & $\begin{array}{c}\text { Pearson } \\
\text { Correlation }\end{array}$ & $.569^{* *}$ & 1 \\
\hline & Sig. (2-tailed) & .000 & \\
\hline & $\mathrm{N}$ & 247 & 247 \\
\hline
\end{tabular}

significant at the 0.01 level (2-tailed).

\section{Motivation with trust}

The results of test of correlation between motivation and trust are presented in Table 16. As shown in the Table, there is a strong in significant positive correlation between overall motivation and trust $\left(\mathrm{r}=.743^{* *} . \mathrm{p}=.000\right)$ because HEI organization closely ties the trust to norms, values and beliefs of organizational culture, managers create a trusting and open environment and the organization enables empowerment in creating high levels of trust. Trust has the highest value of correlation among the other two intrinsic factors of motivation which is training and Recognition of work because the HEI have more trust on their faculty members.

Table 16: Motivation with trust correlation

\begin{tabular}{cccc}
\hline & & Motivation & Trust \\
Motivation & Pearson Correlation & 1 & $.743^{* *}$ \\
& Sig. (2-tailed) & & .000 \\
Trust & $\mathrm{N}$ & 247 & 247 \\
& Pearson Correlation & $.743^{* *}$ & 1 \\
& Sig. (2-tailed) & .000 & \\
$\mathrm{~N}$ & 247 & 247 \\
\hline **. Correlation is significant at the & 0.01 level (2-tailed).
\end{tabular}

\section{DISCUSSION}

\section{Effect of performance appraisal process on employee motivation}

A large number of respondents believe that the performance evaluation approach is fair. Staff motivation increases when staff are subject to regular performance appraisals. A large percentage of respondents believe that their jobs are predetermined. These are the criteria that define the duties an employee must fulfill. These elements are evaluated, then linked to the employee's evaluation. This is important for motivating employees. Employees could be motivated by performance evaluation. 
Research shows that significant numbers of participants indicated that their performance rating was based solely on their performance. You can motivate employees using the current job description as part of an assessment. Most respondents were pleased with their performance and encouraged. This means that employees' actual job descriptions and experience can be used in the assessment process. This could impact employees' motivation and ability for high-level performance. According to the results, most employees believe their salaries are related to their performance in the past year. According to the respondent's performance evaluations concentrate on staff morale, and highlight poor performance.

\section{Effect of performance appraisers on employee motivation}

Raters are well-known for assessing how effectively their employees are doing their jobs. This study's findings show that a large number of people thought the rater was helpful in helping them figure out what they might do better. Managers and supervisors have traditionally been exclusively responsible for evaluating employee performance. According to the findings, a significant percentage of people mentioned the PA in their responses recognizes and rewards successful employees. Furthermore, the findings revealed that a large percentage of respondents said managers often discussed employee job performance with workers. According to the findings, the evaluating manager discusses and identifies competency gaps among faculty members.

\section{Intrinsic factors that influence employee motivation}

In the study, employees' views of skill development and training, as well as trust, were shown to be the most important intrinsic motivational factors. These three factors all influence employee motivation. Research shows that a worker's belief in personal growth affects his or her motivation. Employees benefit from training since it allows them to improve their skill sets. Employers get praise and rewards throughout the assessment period, according to the findings of the study. The research also found that management encourages faculty members to be transparent and trusting of one another. Employee motivation and trust go hand in hand because people feel valued when they work for the business.

\section{Effect of performance appraisal process on employee motivation}

Employee motivation is often attributed to the effectiveness of a company's performance assessment system. The majority of those who took the survey said that the performance assessment method helped them do a better job. Staff motivation rises as a consequence of regular performance assessment. A method for evaluating and encouraging workers' job performance is essential. In order to keep employees motivated, it's essential to connect quantitative performance criteria to individual assessments. Employee motivation and work performance may both benefit from performance evaluation. It's possible to motivate employees by using precise and 
current job descriptions in the assessment process. To increase employee motivation, the performance evaluation identifies and corrects performance problems.

\section{Effect of performance appraisers on employee motivation}

In addition to helping employees understand how to improve their performance, employing a range of raters may increase the accuracy of performance assessments (by decreasing bias) and the impression of fairness among employees. When managers perform an effective job evaluation process, which is important for motivating employees, they may identify personnel. Within the business, subordinates may evaluate their bosses. When it comes to motivating employees, information from subordinate evaluations may be quite helpful in this regard.

\section{Intrinsic factors that influence employee motivation}

Internal factors have an impact on employee satisfaction as well. This is most likely because they speak directly to how employees see their job and how essential and relevant the tasks assigned to them are to those perceptions. When it comes to employees, motivation is an inherent or personal trait that encourages them to adopt a certain attitude about their job. These first impressions have an impact on the motivation of the employees in the company. Problems like an employee's perception of their organization's respect for them and the way they feel about work, among other subjective factors, are important in determining how happy an employee is in their jobs since they are inherent. Recognizing employees is important for boosting employee engagement in the organization's operations. You can guarantee that employees are internally happy with their job, company, and work environment by rewarding their accomplishments and enabling them to participate in decision-making. Because of this, they become more enthused and motivated to complete the project.

\section{RECOMMENDATIONS}

The research advised that organizations should recognize and use intrinsic aspects in their human resource management methods, especially strategic human resource management, to keep people engaged. Other methods that may favorably affect intrinsic variables and promote the formation of high levels of employee motivation include promoting employee engagement in decision making and creativity, and increasing possibilities for personal growth. It should also consider creating rules and procedures that increase employee motivation. Finally, future academics should focus on employee motivation to better grasp this complex notion.

\section{Acknowledgements}

This study was supported by my esteemed teacher, Prof. Cheng Wei Dong (陈卫东), professor at Tianjin University, China. I would like to express my gratitude for his outstanding supervision, monitoring, and continuous encouragement during research, as well as his continued support in the days ahead. I am very appreciative of assistance 
from my family and friends.

\section{REFERENCES}

Abdullah and R Djebavni , 2011. Abdullah, R Djebavni - 2011 Determinants of Job Satisfaction in the UAE: A Case Study of Dubai police, vol. 40

Ali et al., 2012. Ali, S. B., Mahdi, A., \& Malihe, J. (2012). The Effect of Employees' Performance Appraisal Procedure on their Intrinsic Motivation. International Journal of Academic Research in Business and Social Sciences, 2, 12, 1-8.

Annamalai et al.2010. Annamalai, T., Abdullah, A. G. K., \& Alasidiyeen, N. J., (2010). The Mediating Effects of Perceived Organizational Support on the Relationships between Organizational Justice, Trust and Performance Appraisal in Malaysian Secondary Schools. European Journal of Social Sciences, 13 (4), 623-632.

Barringer et al., 2005. Bruce R. Barringer, Foard F. Jones, Donald O. Neubaum, A quantitative content analysis of the characteristics of rapid-growth firms and their founders,Journal of Business Venturing,Volume 20, Issue 5,2005, Pages 663-687,ISSN 0883-9026,https://doi.org/10.1016/j.jbusvent.2004.03.004.

Cardy (1994). Cardy, R. L., \& Dobbins, G. H. (1994). Performance Appraisal: Alternative Perspectives. South Western Publishing Company, Cincinnati, OH.

Caruth et al., 2008. Caruth, D.L. and Humphreys, J.H. (2008), "Performance appraisal: essential characteristics for strategic control", Measuring Business Excellence, Vol. 12 No. 3, pp. 24-32. https://doi.org/10.1108/13683040810900377

Chiang et al., 2008. Chiang, C.F., \& Jang, S.C. (2008). An expectancy theory model for hotel employee motivation. International Journal of Hospitality Management, 27: 313-322.

Collins, C.J., \&Clark, K.D., 2003. Collins,C.J.,\&Clark,K.D.(2003).strategic human resource practices, top management commitment, team social networks and firm performance :the role of human resource practices in creating organizational competitive Advantage . academy of management Journal, 46(6), 740-751.

Davis and Mayer, 1999. Mayer, R. C., \&amp; Davis, J. H. (1999). The effect of the performance appraisal system on trust for management: A field quasi-experiment. Journal of Applied Psychology, 84(1), 123-136. https://doi.org/10.1037/0021$\underline{9010.84 .1 .123}$

Denby and steve, 2010. Denby, Steve. (2010). The importance of training needs analysis. Industrial and Commercial Training. 42. 147-150. 10.1108/00197851011038132.

Dockel et.al. (2006). Dockel, A., Basson, J. S., \&amp; Coetzee, M. (2006). The effect of retention factors on organisational commitment: An investigation of high technology employees. SA Journal of Human Resource Management, 4(2). https://doi.org/10.4102/sajhrm.v4i2.91

Dr. Peter R et al., 2011. Dr. Peter R. Whipp, Heidi Hutton, J. Robert Grove \& Ben Jackson (2011) Outsourcing Physical Education in primary schools: Evaluating the impact of externally provided programmes on generalist teachers, Asia-Pacific Journal of Health, Sport and Physical Education, 2:2, 67-77, DOI: $10.1080 / 18377122.2011 .9730352$

Heneman 1986. Heneman, R. L. (1986). Pay for performance: Exploring the merit system. 
Herbert, (2009). Herbert, 2009. The influence of discipline management by Headteachers on students' academic performance in selected private secondary Schools of Busiro County in Wakiso District.

Hunjra et al., 2010. Hunjra, AI, Chani, MI, Aslam, S, Azam, M \& Rehman, KU (2010), 'Factors effecting job satisfaction of employees in Pakistani banking sector', African Journal of Business Management, vol 4, no. 10, pp. 2157-2163

Ichniowski,C. and Shaw, 2009. Ichniowski,C.,\&Shaw,K.(2009).the effect of human resource management system so economic performance :an international comparison of us and japanese plants .management science, 75 (5), 704-721.

Jayawarna et al., 2007. Jayawarna,D.,Wilson,A.,\&Macpherson,A.(2007). training commitment and performance in manufacturing smes .journal of small business and enterprise Development14(2),321-338

Jun, et.al. 2006. Jun, M., Cai, S., \& Shin, H. (2006). TQM practice in maquiladora: antecedents of employee satisfaction and loyalty. Journal of Operations Management, 24, 791-812.

Kamalian.et.al. 2010. Kamalian, A. R., Yaghoubi, N. M., \& Moloudi, J., (2010). Survey of Relationship between Organizational Justice and Empowerment (A Case Study). European Journal of Economics, Finance and Administrative Sciences, 24, 165-171

Kirai \& Kisang,2016. Kisang, F., \& Kirai, M. (2016). EFFECTS OF PERFORMANCE APPRAISAL ON EMPLOYEE MOTIVATION IN COMMERCIAL BANKS: A CASE OF EQUITY BANK, KENYA. Strategic Journal of Business and Change Management, 3(4), 29, 520-542.

Koretz et al. 1996. Koretz, D., Mitchell, K., Barron, S., \&amp; Keith, S. (1996). Final report: Perceived effects of the maryland school performance assessment program. PsycEXTRA Dataset. https://doi.org/10.1037/e652172011-001

Lewis et al., (2003). Lewis, P., Sauders, M., \& Research Methods for Business students, Third Edition. London: Prentice Hall. Thornhill, A. (2003).

Matthew et al. 2009. Matthew, J., Grawhich, \& Barber, L. K., (2009). Are you Focusing both Employees and Organizational Outcomes? Organizational Health Initiative at Saint Louis University (ohi.slu@edu), 1-5.

McKenna et al. 2002. McKenna, E. F., \&amp; Beech, N. (1999). The essence of Human Resource Management. Prentice Hall.

Ohabunwa, 2009. Ohabunwa,S.(2009). Nigeria business environment in the new millennium. A paper presented for hrdbunilag on renovating our corporate management practices for the New Millemium, Wednesday19thMay.

OJOKUKU, 2013. OJOKUKU, R.M. EFFECT OF PERFORMANCE APPRAISAL SYSTEM ON MOTIVATION AND PERFORMANCE OF ACADEMICS IN NIGERIAN PUBLIC UNIVERSITIES Vol.3 No.03 [20-28] | June-2013

Okeyo, et al., 2010. GL Okeyo, P Mathooko, N Sitati - 2010 - Nairobi, Kenya, The effects of performance appraisal system on civil servant's job performance and motivation in Kenya

Popoola (1990). Fabunmi, J. O., \& Popoola, A. O. (1990). Legal Education in Nigeria: Problems and Prospects. Verfassung Und Recht in Übersee / Law and Politics in Africa, Asia and Latin America, 23(1), 34-55. http://www.jstor.org/stable/43109931 
Porter and M. E, 2008. Porter, M. E. (2008). Competitive advantage: Creating and sustaining superior performance. Free Press.

Prisca oluoch (2006). Prisca oluoch (2006), diversity management practices of commercial banks in kenya. Unpublished mba research project, school of business, university of nairobi.

Qureshi et al., 2007. Qureshi,M.T.,Ramay,I.,Marwat,A.,\&Zubair,M.(2007).impact of human resource management(HRM)practices on employees performance muhammad ali jinnah University,Islamabad

Saeed S and Shah, 2016. Saeed, S., \& Shah, F. M. (2016). IMPACT OF PERFORMANCE APPRAISAL ON EMPLOYEES' MOTIVATION IN ISLAMIC BANKING. Arabian Journal of Business and Management Review, 5, 7, 1-8.

Schuler 2002. Levitan, B., Lobo, J., Schuler, R. et al. Evolution of Organizational Performance and Stability in a Stochastic Environment. Computational \&amp; Mathematical Organization Theory 8, 281-313 (2002). https://doi.org/10.1023/A:1025416617948

Selvarajan and Cloninger, 2012. Cloninger and Selvarajan (2009) Selvarajan, R. and Cloninger, P.A. (2009), "The influence of job performance outcomes on ethical assessments",

Personnel Review, Vol. 38 No. 4, pp. 398-412. https://doi.org/10.1108/00483480910956346

Selvarajan and Cloninger, 2012. T. T. Selvarajan \& Peggy A. Cloninger (2012) Can performance appraisals motivate employees to improve performance? A Mexican study, The International Journal of Human Resource Management, 23:15, 3063-3084, DOI: 10.1080/09585192.2011.637069

Shen, 2004. Shen, J. (2004), "International performance appraisals: Policies, practices \& determinants in the case of Chinese multinational companies", International Journal of Manpower, Vol. 25 No. 6, pp. 547-563. https://doi.org/10.1108/01437720410560442

Westover and L.A., 2010. Westover, L.A. (2010). Enhancing long-term worker productivity and performance: The connection of key work domains to job satisfaction and organizational commitment. International Journal of Productivity and Performance Management, 59(4):372-387

Yaseen, 2013. Yaseen. A. (2013) Effect of compensation factors on employee satisfaction: International Journal of Human Resource Stusies. ISSN 2162- 3058 2013, Vol. 3. 